Ege Tıp Dergisi / Ege Journal of Medicine 2018;57(1):51-53

\title{
Servikal ektopik timus: Yenidoğanda nadir bir boyun kitlesi
}

Cervical ectopic thymus: A rare cervical mass in a newborn

Ülgen Çeltik ${ }^{1} \quad$ Emre Divarcı $^{1} \quad$ Zafer Dökümcü $^{1} \quad$ Sevinç Kalın $^{2}$ Ahmet Çelik $^{1}$

${ }^{1}$ Ege Üniversitesi Tıp Fakültesi, Çocuk Cerrahisi Anabilim Dalı, İzmir, Türkiye

${ }^{2}$ Ege Üniversitesi Tıp Fakültesi, Pediatrik Radyoloji Bilim Dalı, İzmir, Türkiye

\section{Öz}

Servikal ektopik timus (SET) çocukluk çağı servikal kitlelerinin nadir nedenlerinden birisidir. Bu çalışmada kliniğimize yenidoğan döneminde servikal şişlik nedeni ile başvuran iki SET olgusunun sunulması amaçlandı. Yenidoğan döneminden itibaren sol üst servikal bölgede ağrısız şişlik ile başvuran iki olgu değerlendirildi. Her iki olguda, fiziksel muayenede; palpasyonda yumuşak, fluktuasyon vermeyen ağrısız şişlik mevcuttu. Olgulara malign kitlelerin ekartasyonu amacı ile doku örneklemesi planlandı. Kitleler tümü ile çıkarıldı. Patolojik inceleme sonucu ektopik timus dokusu olarak raporlandı. Her iki olgunun, operasyon sonrası izleminde herhangi bir yakınması mevcut değildi. SET servikal şişlik ile başvuran yenidoğan olgularda akılda bulundurulmalıdır. Nadir olması ve kesin tanıya kolay ulaşılamaması nedeni ile diğer tanıların ekartasyonu amacı ile doku örneklemesi planlanmalıdır.

Anahtar Sözcükler: Servikal ektopik timus, timus, konjenital anomali, çocuk.

\begin{abstract}
Cervical ectopic thymus (CET) is a rare cause of cervical mass in childhood. The aim of this study is to present two CET cases that were referred to our clinic with cervical swelling in neonatal period. Two cases who had painless swelling in left upper cervical region beginning from the neonatal period were evaluated. In both cases, a soft nonfluctuant painless swelling in the palpation was detected in the physical examination. To exclude the malign mass, tissue sampling was planned. The masses were excised totally. As a result of pathological examination it was reported as ectopic thymus tissue. No complaint was recorded during the postoperative period. CET should be taken into consideration in the neonatal cases applying with cervical swelling. It is rare and not easy to establish a definitive diagnosis, tissue sampling should be considered for the exclusion of other diagnoses.
\end{abstract}

Keywords: Cervical ectopic thymus, thymus, congenital disease, children.

\section{Giriş}

Servikal ektopik timus (SET), çocukluk çağı servikal kitlelerinin nadir nedenlerinden birisidir. SET, timusun embriyolojik iniş yolu üzerinde meydana gelen bir duraksama nedeni ile oluşmaktadır. Mandibula köşesinden anterior mediastene göçü sırasında meydana gelen bu duraksama, iniş yolu üzerinde herhangi bir yerde olabilmektedir (1). Stridor, disfaji, dispne gibi semptomlarla herhangi bir yaşta kendini belli edebildiği gibi çoğunlukla asemptomatik şişlik şeklinde fark edilmektedir $(1,2)$. Kliniğimize yenidoğan döneminde servikal şişlik nedeni ile başvuran iki SET olgusunun klinik, radyolojik ve patolojik özelliklerinin tartışılması amaçlandı.

\section{Yazışma Adresi: Ülgen Çeltik}

Ege Üniversitesi Tıp Fakültesi, Çocuk Cerrahisi Anabilim Dalı, İzmir, Türkiye

Makalenin Geliş Tarihi: 19.12.2016 Kabul Tarihi: 08.02.2017

\section{Olgu Sunumu}

Yirmi günlük ve 2 aylık iki erkek olgu, yenidoğan döneminden bu yana fark edilen sol üst servikal bölgede şişlik nedeni ile başvurdu. Mevcut şişlik solunum sıkıntısı, yutma güçlüğü gibi belirtilere yol açmamaktaydı. Fizik muayenede cilt üzerinde eritem veya fluktuasyon mevcut değildi. Birinci olguda ultrasonografide sol submandibuler alanda parotis derin lobu ve sol submandibuler bezi baskılayan yaklaşık $3.5 \times 2 \mathrm{~cm}$ boyutlarında heterojen, düzgün konturlu kitle lezyonu saptanırken ikinci olguda benzer özelliklere sahip boyutları 40x22 mm olan lezyon saptandı. USG'de timus dokusuna benzerliği nedeni ile ektopik timus düşünülse de Doppler incelemede belirgin vaskülarizasyon tespit edilmesi sonucu malign servikal kitleler ekarte edilemedi. Biyokimya tetkikleri tümör belirteçleri dahil, her iki olguda olağandı. MR görüntülemede; ilk olguda sol parotis bezi hemen 
inferiorundan, parafaringeal alana doğru uzanan 2.8×3.2×3.3 cm boyutlarında T2A'da ılımlı hipointens T1A'da hipointens kitle lezyonu saptanırken, ikinci olguda sol parotis bezi lojunda submandibuler alana doğru uzanan $3.5 \times 2.5 \mathrm{~cm}$ boyutlu lezyon saptandı (Şekil-1).
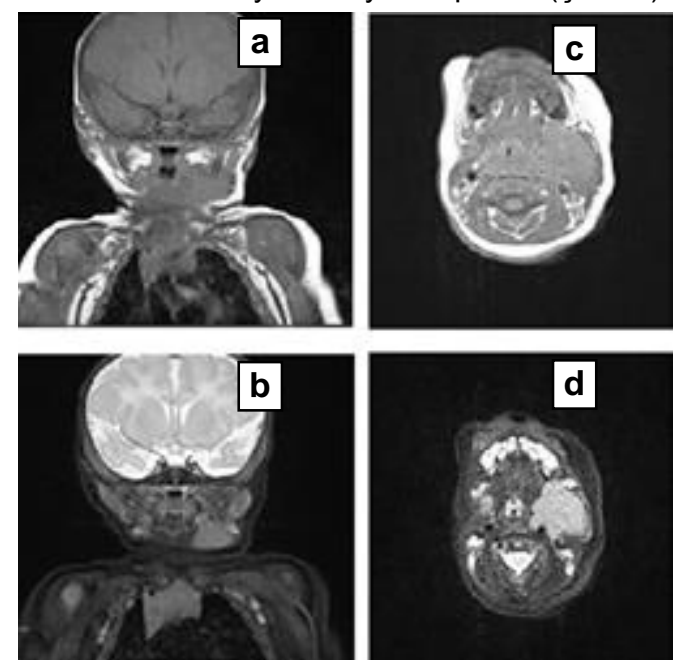

Şekil-1. MRG T1A görüntülerde ılımlı hipointens, T2A görüntülerde hipointens kitle lezyonu.

Olgular ektopik timus, servikal nöroblastom, kapiller hemanjiom gibi ön tanılar ile operasyona alındı. Total olarak eksize edilen kitleler makroskopik görünüm itibarı ile benzerlik göstermeleri yanında, iyi sınırlı, yumuşak, çevre dokulara invazyon göstermeyen total olarak kolaylıkla etraf dokulardan ayrılabilen, ince kapsüllü, minimal lobulasyon gösteren, krem pembe renkli bir yapıya sahipti. Histopatolojik inceleme ektopik timus dokusunu doğruladı. Postoperatif uzun dönem izlemde iki olguda da herhangi bir şikayet saptanmadı.

Her iki olgunun yasal vasilerinden tıbbi verilerinin yayınlanabileceğine ilişkin yazılı onam belgesi alındı.

\section{Tartışma}

SET timik embriyogenez sırasında meydana gelen migrasyon defekti ya da timofarengeal kanalın persiste etmesi sonucu oluşur (1-4). Mandibuler alandan anterior mediastene kadar uzanan hat üzerinde herhangi bir yerde görülebilir. Eğer embriyolojik iniş yolu üzerinde herhangi bir yerde yerleşim gösteriyorsa aberan timus; farenks, trakea, özefagus, posterior mediasten gibi iniş yolu üzerinde olmayan bir yerde görülüyorsa ektopik timus olarak adlandıııır $(2,5)$. Ancak zaman zaman tanımlama karmaşası literatürde de yaşanmaktadır $(2,4,6)$.

Olguların \%90'ı asemptomatik seyrederken \%10'unda ise yutma disfonksiyonu, disfaji, solunum güçlüğü gibi semptomlar, tortikolis görülebilir $(1,2)$. Bu bası semptomları travma sonrası, enfeksiyon durumlarında ani boyut artışı ile daha belirgin olarak görülebilmektedir $(2,3)$. Çalışmamızda her iki olguda ek klinik yakınma yaratmayan servikal şişlik mevcuttu.
Literatür değerlendirildiğinde ektopik timusun nadir rastlanan bir patoloji olduğu görülmektedir. Gerçek insidansı bilinmemekle birlikte 1993 yılında yayımlanan 3236 olguluk otopsi değerlendirilmesinde 34 adet anormal yerleşimli timus saptandığı bildirilmiştir. Aynı çalışmada 68000 operasyon materyali değerlendirilmiş ve 10 adet servikal ektopik timus vakası saptanmıştır (7). 2014 yılında Japonya da ani bebek ölümü sonucu kaybedilen vakalar ile yapılan otopsi serisinde 21 olgunun 7'sinde (\%33) servikal ektopik timus saptanmıştır (8).

Yerleşim yeri ya da tarafının sıklığı açısından literatürdeki seriler farklılık göstermektedir. Song ve ark. (2) tarafından yayınlanan 13 hastalık seride 7 olguda sol servikal bölge yerleşimli olduğu görülmüştür. Zielke ve ark. (9) tarafından yayımlanan bir çalışmada 46 olgu ile yapılan literatür taramasında ise \%56 oranla sağ taraf yerleşimli olduğu belirtilmiştir. Olgularımızın her ikisinde de sol servikal yerleşimli SET mevcuttu.

Her iki olgumuz erkekti ve yenidoğan döneminde servikal şişlik nedeni ile başvurmuştu. Fakat lezyonun her yaşta görülebildiği literatürdeki verilerden anlaşılmaktadır (2-4). Yaşla birlikte timus dokusu gerileme gösterdiği için tanı yüksek oranla yaşamın ilk ayları içinde konulabilmektedir. SET görülme sıklığı literatürde de erkek olgularda kızlara oranla daha yüksektir (1). Ancak literatürde de tarafımızca da bu duruma özel bir açıklama getirilmemiştir.

Ektopik timus olgularında doğal yerleşiminde bir timus dokusunun olup olmadığı değerlendirilmelidir. İki olgumuzda da normal lokalizasyonda timus dokusu mevcuttu. Timektomi sonrası olgularda total lenfosit sayısında bir değişiklik görülmezken T lenfosit sayısında bir miktar düşüklük görüldüğü bazı yazarlar tarafından belirtilmiştir $(1,2)$. Her iki olgumuzda preoperatif değerlendirmede normal lokalizasyonda timus dokusu saptandığı için uzun dönem incelemede klinik bir sorunla karşılaşılmamıştır.

Servikal kitle ayırıcı tanısında USG yerleşim yeri, kistik ya da solid komponentlerin, ekojenitenin belirlenmesi ve vaskülaritenin ortaya konulmasında kullanılabilecek pratik bir yöntemdir. Koumanido ve ark. (5), 5 SET olgusundan iki olguya sadece USG ile tanı koyulduğunu, üç olguda ise tanının ancak rezeksiyon ile mümkün olduğunu vurgulamıştır. Ayırıcı bir tanı olarak SET'in akılda bulundurulması halinde USG ile tanı konulmasının mümkün olduğunu belirtmişlerdir. USG'de en belirgin bulgu timus dokusu ile benzer ekojeniteye sahip olması ve bazı vakalarda normal timus dokusu ile arasında bir köprü mevcut olmasıdır. Literatürde ektopik timusun, akılda bulundurulması halinde, USG ile tanısının mümkün ve yeterli olduğu ve hatta semptomatik vakalar dışında eksizyon uygulanmaksızın USG ile takibin yeterli olduğu vurgulanmıştır $(4,6,10)$. Han ve ark. (3) USG ile izlem konusunu çalışmalarında özellikle vurgulamışlardır. 
Literatürde erişkin yaşlarda görülen timik diferansiasyon ile oluşan ektopik hamartomatöz timoma gibi servikal kitleler mevcuttur. Literatürde değerlendirilen SET'li olgulardan erişkin bir hastada malign özellikte hücreler içeren trakeal kitle saptanmıştır ve bu kitlenin natürü ile ilgili net bir bilgi verilememiştir. $\mathrm{Bu}$ sebeple malign dönüşüm olmadığını söylemek bu bilgiler ışığında oldukça zordur (5). Eksizyon, ayırıcı tanı gerekliliğ dışında malignite riskine karsı gerekli gibi görünmektedir.

\section{Kaynaklar}

1. Wang J, Fu H, Yang H, et al. Clinical management of cervical ectopic thymus in children. J Pediatr Surg 2011;46(8):E33-E36.

2. Song I, Yoo SY, Kim JH, et al. Aberrant cervical thymus: Imaging and clinical findings in 13 children. Clin Radiol 2011;66(1):3842.

3. Han BK, Yoon HK, Yuh LS. Thymic ultrasound: Diagnosis of aberant cervical thymus. Pediatr Radiol 2001;31(7):480-7.

4. Schloegel LJ, Gottschall JA. Ectopic servical thymus: Is empric surgical excision necessary? Int J Pediatr Otorhinolaryngol 2009;73(3):475-9.

5. Koumanidou C, Vakaki M, Theophanopoulou M, et al. Aberrant thymus in infants: Sonographic evaluation. Pediatr Radiol 1998;28(12):987-9.

6. Slovis TL, Meza M, Kuhn JP. Aberrant thymus - MR assessment. Pediatr Radiol 1992;22(7):490-4.

7. Bale PM, Sotelo-Avila C. Maldescent of the thymus: 34 necropsy and 10 surgical cases, including 7 thymuses medial to the mandible. Pediatr Pathol 1993;13(6):181-90.

8. Kotani $\mathrm{H}$, Ishida $\mathrm{T}$, Miyao $\mathrm{M}$, et al. Ectopic cervical thymus: A clinicopathological study of consecutive, unselected infant autopsies. Int J Pediatr Otorhinolaryngol 2014;78(11):1917-22.

9. Zielke AM, Swischuk LE, Hernandez JA. Ectopic cervical thymic tissue: Can imaging obviate biopsy and surgical removal? Pediatr Radiol 2007;37(11):1174-7.

10. Bilateral ectopic cervical thymus presenting as a neck mass: Ultrasound and magnetic resonance imaging. Pediatr Int 2016;58(9):943-5. 